\title{
Representação na monarquia brasileira
}

Political Representation during the Brazilian Empire

\section{Miriam Dolhnikoff}

Professora no Departamento de História da Universidade de São Paulo

e-mail:miriamdk@uol.com.br

\section{Resumo}

Este artigo analisa o governo representativo no Brasil oitocentista do ponto de vista do exercício da cidadania e dos debates em torno da normatização das eleições. Neste sentido, dialoga com o texto de Hilda Sabato na medida que procura demonstrar que também na monarquia constitucional brasileira a relação de representação foi fundamental para o funcionamento do regime, colocando dilemas e desafios próprios a uma nação americana que se tornava independente.

\section{Abstract}

This paper analyses representative government in 19th century Brazil from two focal points: citizenship and the debates concerning elections. By doing so, it fosters a dialogue with Hilda Sabato's essay as it demonstrates that during the constitutional monarchy in Brazil political representation was also fundamental for the regime, placing specific dilemmas and challenges to a newly independent Nation.

\section{Palavras-chave}

império, cidadania, representações políticas, práticas políticas

\section{Keywords}

empire, citizenship, political representations, political practices 
PITKIN, Hanna. The concept of representation. Los Angeles: University of California Press, 1967; MANIN, Bernard. Los principios del gobierno representativo. Madrid: Alianza Editorial, 1998; SARTORI, Giovanni. A teoria da representação no Estado representativo moderno. Belo Horizonte: Edições da Revista Brasileira de Estudos Políticos, Faculdade de Direito da Universidade de Minas Gerais, 1962.
0 excelente texto de Hilda Sabato traz ricas contribuições para se pensar as experiências de representação política do século XIX em países recém organizados a partir de um passado colonial. A análise se concentra na organização republicana, o que obviamente exclui a monarquia brasileira. Mas um exercício interessante, ao meu ver, é, apesar das óbvias diferenças entre estas repúblicas e a nossa opção monárquica, procurar traçar algumas semelhanças entre estas experiências. A proposta se justifica na medida que repúblicas e monarquias constitucionais no século XIX eram variações de governos representativos, modelos surgidos na Europa e Estados Unidos na transição do século XVIII e XIX e que tinham em comum o estabelecimento de novas relações entre Estado e sociedade, com a inclusão na participação política de setores antes dela alijados. Neste texto pretendo alinhavar alguns elementos que apontam para o debate no Brasil sobre a construção da relação entre representantes e representados, tanto do ponto de vista da cidadania, como do ponto de vista da normatização das eleições.

A análise da cidadania na América hispânica efetivada por Sabato ganha imensa riqueza a partir do pressuposto de que os governos representativos do século XIX não podem ser examinados sob a ótica das democracias modernas e sim devem sê-lo de acordo com a especificidade do periodo. Desta forma torna-se possível avaliar a natureza e conteúdo da cidadania e sua importância no jogo político, inclusive tomando em conjunto as diversas experiências republicanas latino-americanas. 0 mesmo ponto de vista deve ser adotado para o Brasil. A organização da monarquia constitucional seguiu os modelos prevalecentes na época, notadamente a Inglaterra e a França. 0 que significava, conforme as análises de Bernard Manin, Hannah Pitkin e Giovani Sartori, uma profunda remodelação do Estado, na qual a inclusão de participação não impedia que se constituisse um regime de natureza excludente, uma vez que eram preservados a iniciativa política e o poder decisório nas mãos de determinados grupos. Manin aponta inclusive a escolha de eleições como forma de indicar os representantes como uma opção que visava garantir que apenas uma elite selecionada pudesse efetivamente ocupar os cargos públicos ${ }^{1}$.

Inclusão e exclusão conformaram, portanto, estas experiências e, neste contexto, a construção da cidadania foi um processo pelo qual uma gama de indivíduos passou a gozar de direitos políticos, sem que, contudo, isto tivesse uma perspectiva universalizante como nas democracias modernas. Prevaleceu uma concepção cara ao liberalismo europeu do século XIX de que era preciso garantir a qualidade dos representantes, de modo que homens devidamente qualificados chegassem ao parlamento habilitados para decidir de acordo com os "verdadeiros interesses nacionais". Um representante de qualidade seria escolhido se o voto fosse exclusivo de eleitores também qualificados. A conseqüente limitação dos setores da população que participariam do jogo político através do voto era tida como virtuosa, da mesma forma que no século XX, inversamente, se considerará virtuosa a expansão deste eleitorado.

Por esta razão, no século XIX muitos defendiam a adoção de critérios de limitação da cidadania política, tanto para votar como para ser eleito, fossem exigências censitárias fossem de alfabetização. Era considerado necessário que apenas aqueles com melhor "discernimento" pudessem eleger e serem eleitos, de modo a resultar em um parlamento capaz de formular o "bem comum". As virtudes que conferiam este "discernimento" poderiam ser a independência material, concretizada pela propriedade e 
2

MANIN, Bernard. Los principios del gobierno representativo. Madrid: Alianza Editorial, 1998. p.163.

RONSAVALLON, Pierre. La consagración del ciudadano: Historia del Sufragio Universal en Francia. San Juan: Instituto Mora, 1999.

4

ALENCAR, José de. Sistema representativo. Brasilia: Senado Federal, 1997. p.76. ou pela renda, a capacidade intelectual, concretizada pela educação, etc. A preocupação em garantir a escolha de uma elite portadora de virtudes que a diferenciava da massa da população, fosse por sua riqueza, fosse por sua sabedoria, resultou, na Inglaterra e na França, na restrição ao direito de voto e ao direito de ser eleito. Nos dois paises o voto era censitário e só proprietários poderiam ser candidatos. Nos Estados Unidos, por outro lado, desde o início os liberais constataram que não era necessário impor restrições legais para votar e ser eleito, uma vez que as eleições por si só garantiriam que apenas uma elite pudesse concorrer aos cargos públicos. Segundo Manin, levou quase "cem anos para que os europeus chegassem a ver esta propriedade das eleições ou, ao menos, que recorressem a ela para assegurar a distinção dos representantes"2, prescindindo assim de regras que limitassem o direito de voto e de ser eleito.

As restrições ao direito de voto calcavam-se na diferenciação entre cidadania civil e cidadania política. Como aponta Pierre Ronsavallon ao analisar o caso francês, participar do processo eleitoral não era considerado um direito inerente do indivíduo, mas uma função pública que apenas alguns homens estavam qualificados para exercer. Os direitos residiam no campo da cidadania civil e não da cidadania política. Apenas quando surgiram, no final do século XIX, setores sociais com força suficiente para pressionarem por mudanças é que o voto passou a ser considerado um direito associado à idéia de inclusão social. A concepção de que a participação eleitoral deve se estender a todos, associando representação política com ampla representatividade e inclusão social, foi portanto um fenômeno emergente no final dos oitocentos. ${ }^{3}$ Até mesmo um publicista como José de Alencar, que defendia o sufrágio universal, afirmava: "nenhuma das leis fundamentais dos países representativos garante expressamente o direito do sufrágio como um direito absoluto do cidadão"4. Afinado com o debate sobre representação na Europa e Estados Unidos, Alencar salientava que a cidadania civil era condição do exercício da cidadania política, mas nem todos que gozavam da primeira deveriam ter acesso direto à segunda.

0 exercício da cidadania colocou problemas semelhantes no Brasil àqueles estudados por Hilda Sabato, uma vez que se tratava também aqui do desafio de construir um governo representativo em um território de passado colonial com profunda estratificação social. E este desafio passou também aqui por definir quem pertencia e quem não pertencia à comunidade política, quem teria o direito de exercer o papel de representante e quem seria representado, enfim, quem seria cidadão.

No Brasil é possivel identificar as três formas de exercícios da cidadania apontadas pela autora: eleitoral, militar e expressão de opinião pública. No caso da cidadania através da ação militar, ela também se constituiu no Brasil através da Guarda Nacional, nossa milícia cidadã. No que diz respeito à opinião pública, a imprensa teve aqui papel similar ao apontado por Sabato na América hispânica, embora ainda esteja para ser estudado no caso brasileiro o papel de associações surgidas da sociedade civil.

No que diz respeito à participação eleitoral, a opção pelo voto censitário na constituição brasileira de 1824 estava de acordo com a visão européia de que esta era uma condição para a "boa representação". Em que pese as restrições, no entanto, o eleitorado brasileiro não estava fora dos padrões da época. No que diz respeito ao universo de votantes, conforme aponta José Murilo de Carvalho, 13\% da população total (excluindo os escravos) tinha direito de voto, de acordo com o recenseamento de 1872. Em torno 
CARVALHO, José Murilo de. Cidadania no Brasil: o longo caminho. Rio de Janeiro: Civilização Brasileira, 2001. p.31

RONSAVALLON, Pierre. La consagración del ciudadano: Historia del Sufragio Universal en Francia. San Juan: Instituto Mora, 1999. p.174.

NICOLAU, Jairo Marconi. As distorções nas representações dos estados na Câmara dos Deputados brasileira. Dados, Rio de janeiro vol.40, n.03, 1997

MANIN, Bernard. Los principios del gobierno representativo. Madrid: Alianza Editorial, 1998. p.248.

Veja-se sobre este debate SLEMIAN, Andréa. Seriam todos cidadãos?: os impasses na construção da cidadania nos primórdios do constitucionalismo no Brasil (1823-1824). In: JANCSÓ Istvan (org.). Independência: história e historiografia. São Paulo: Hucitec, 2005. p.829-848. de 1870, na Inglaterra eram apenas 7\%, na Itália, 2\% e na Holanda 2,5\% 5 . Mas é preciso tomar cuidado com estas comparações. No Brasil as eleições eram realizadas em dois graus (votantes escolhiam eleitores que por sua vez escolhiam deputados e senadores), seguindo o modelo adotado na França revolucionária. Como aponta Rosanvallon, o voto de primeiro grau tem uma natureza distinta do de segundo grau. Só este último é efetivamente uma decisão política, enquanto os votantes de primeiro grau exercem apenas um papel de legitimação do processo eleitoral: "as assembléias primárias não fazem mais que designar os eleitores: procedem somente a uma espécie de legitimação original do procedimento representativo. Porém, as verdadeiras eleições têm lugar em outra parte, nas assembléias eleitorais, as de segundo grau, que só reúnem a centésima parte dos cidadãos ativos"6. Não se pode comparar como iguais a participação dos votantes de primeiro grau no Brasil com a participação em eleições em paises onde o pleito era direto. São participações de natureza distintas, uma de legitimação, outra de decisão. Considerando que o número de eleitores de segundo grau no Brasil era muito inferior ao de votantes (cada 40 votantes escolhiam um eleitor, segundo lei aprovada em 1846), provavelmente se tomarmos apenas os eleitores de segundo grau o padrão de participação no Brasil não se apresentaria tão superior ao padrão europeu. De todo modo, dele não se distanciava e não se pode negar que mesmo com função apenas de legitimação, o voto de primeiro grau era uma forma de incluir setores mais amplos da população no jogo político.

A renda exigida pela Constituição brasileira para ser votante, mesmo indexada em prata como mandava lei aprovada em 1846, era baixa. Exigiase uma renda anual de 100 mil réis e, como aponta Jairo Nicolau, baseado em pesquisa realizada por Mircea Buescu, trabalhadores de ofícios modestos recebiam bem mais do que isto. Um carpinteiro, por exemplo, recebia por ano cerca de 500 mil réis, renda suficiente para ser votante, eleitor e candidato a deputado. Cocheiros, copeiros, cozinheiros, jardineiros e lavradores recebiam em torno de 200 e 400 mil réis anuais7, podendo, portanto, ser eleitores e até mesmo candidatos a deputado. Mas o fato de terem renda suficiente para serem eleitos não garantia a estas camadas da população condições reais de se elegerem. Se, como aponta Manin, as eleições são um meio de restringir, para além das regras constitucionais, o universo daqueles que têm condições reais de serem eleitos, no século XIX, segundo ele, eram as notabilidades locais as favorecidas: os elementos que interferiam na seleção dos candidatos eram "sua rede de conexões locais, sua importância social ou a deferência que provocavam. (...) a eleição selecionava um tipo particular de elite: os notáveis. 0 governo representativo se iniciou, portanto, como um governo de notáveis"8. No Brasil, como se sabe, a propriedade da terra e de escravos foi o elemento mais importante para estabelecer as conexões locais e assim credenciar o indivíduo como candidato.

Um fator importante para a ampla participação, considerados os padrões da época, foi o fato de que se conferia direito de cidadania aos libertos. Na Assembléia constituinte de 1823, este foi um tema de amplo debate, vencendo a perspectiva liberal de que todo homem livre, desde que possuidor de determinados requisitos, deveria gozar de cidadania 9 .

Havia, por outro lado, consenso sobre a exclusão de escravos e indígenas. Na concepção de cidadania política prevalecente no século XIX a exclusão do escravo não era um problema. Como aponta José de Alencar, a incapacidade política derivava, antes de mais nada, da incapacidade civil, 
10

ALENCAR, José de. Sistema representativo. Brasília: Senado Federal, 1997. p 89.

11

MADISON, James; HAMILTON, Alexander; JAY, John. Os artigos federalistas, 1787-1788. Rio de Janeiro: Nova Fronteira, 1993. p.363.

\section{2}

SLEMIAN, Andréa. Seriam todos cidadãos?: os impasses na construção da cidadania nos primórdios do constitucionalismo no Brasil (18231824). In: JANCSÓ, Istvan (org.). Independência: história e historiografia. São Paulo, Hucitec: 2005.

13

Anais da Assembléia Constituinte de 1823, Vol II, p.92.
[...] antes de cidadão, o homem é pessoa. Dessa qualidade depende o título de membro da comunhão. Desde, pois, que o individuo se acha privado da atividade de seu direito civil, fica virtualmente impedido de exercer o direito político. ${ }^{10}$

0 escravo estava fora da sociedade civil e, portanto, não cabia considerá-lo como membro da sociedade política. 0 mesmo problema foi enfrentado nos Estados Unidos. Madison, por exemplo, advogava que o escravo sequer deveria ser contabilizado no cálculo da população que deveria servir de base para estabelecer o número de deputados a que cada estado teria direito: "os escravos são considerados propriedades, não pessoas. Devem, portanto, ser incluídos em cálculos de tributação, que se fundam na propriedade, e ser excluídos da representação, que é regulada pelo censo das pessoas"11. Madison argumentava neste ponto contra as pretensões dos grandes proprietários de escravos do sul dos Estados Unidos, que reivindicavam serem os escravos contabilizados para efeito de cálculo da população, de modo a garantirem para seus estados um número maior de representantes. Acabou prevalecendo na constituição norte-americana uma solução intermediária, pela qual o escravo contava como três quintos de uma pessoa.

Mas se a exclusão do escravo e do indígena parecia natural aos construtores do governo representativo brasileiro, a presença da escravidão trazia problemas conceituais na definição da cidadania. Assim, o debate na Constituinte de 1823 concentrou-se na questão de se a cidadania estava ou não vinculada à nacionalidade ${ }^{12}$. Tratava-se de definir se todo brasileiro gozava de cidadania civil ou não. Note-se que não havia diferença nas conseqüências práticas, pois em ambos os casos ficavam de fora escravos e índios selvagens e eram incluídos negros libertos e índios assimilados. Porque então a discussão sobre se deveria se fazer diferença entre ser brasileiro e ser cidadão brasileiro ocupou várias sessões da Constituinte com acirrados debates?

A resposta para esta pergunta pode estar na fala do deputado Vergueiro no decorrer da discussão: considerar que existissem brasileiros que não eram cidadãos significava implodir a diferença entre cidadania civil e a cidadania política. Segundo Vergueiro:

\footnotetext{
Pouco importa que nem todos gozem dos mesmos direitos e que alguns não exercitem os direitos políticos, por não terem os requisitos que a lei exige: todos eles são hábeis para o exercício de todos os direitos uma vez que consigam as qualificações da lei. Servindo-se de um exemplo do presente projeto [ele se refere ao projeto de constituição então em discussão] vê-se que quem não possui certo rendimento não pode votar para deputado, mas se ele trabalhar e conseguir este rendimento passa logo a exercitar esse direito. E poderá se dizer que não era cidadão antes de ter esse rendimento e que se fez cidadão logo que o adquiriu? Não me parece política nem justa esta diferença. ${ }^{13}$
}

Para além da questão conceitual, estava uma questão política de fundo: considerar que todos os brasileiros eram cidadãos civis significava acenar com a possibilidade de um dia vir a exercer a cidadania política, elemento importante de cooptação do regime representativo, excludente mas sempre acenando com a possibilidade de inclusão. Escravos e índios selvagens estavam excluídos da cidadania civil, mas por que sequer podiam ser considerados brasileiros segundo a proposta de Vergueiro. Uma vez liberto, no caso do escravo, ou domesticado, no caso do índio, imediatamente tornava-se brasileiro e também cidadão, podendo eventualmente um 
dia adquirir cidadania política. A cidadania política era assim um direito de todo brasileiro, que ele poderia ou não gozar dependendo exclusivamente de suas virtudes individuais, por exemplo, em perspectiva tipicamente liberal, se tivesse as virtudes necessárias para o trabalho morigerado para um dia obter os rendimentos exigidos por lei. Das qualidades do indivíduo dependia a cidadania política, o que significava que aquele que não a obtivesse deveria creditar o mal a si próprio, mas a cidadania civil, que remetia aos direitos naturais do indivíduo, de nada poderia depender, bastando ser brasileiro. Por isso seria inaceitável a diferença entre ser brasileiro e ser cidadão. Era a condição de brasileiro que se devia negar a índios selvagens e escravos e não a condição de cidadão, negada apenas em decorrência da ausência da primeira.

De outro lado, a posição de Ferreira França, ao defender a distinção entre ser brasileiro e gozar de cidadania civil tinha embutida a defesa de um ponto no mínimo sensivel para os legisladores: o reconhecimento pela constituição de que havia uma parcela da população que habitava o território reduzida à condição de escravos. A posição de Vergueiro significava silenciar sobre a escravidão. Ao contrário de Ferreira França que afirmava:

14

Anais da Assembléia Constituinte, p.93.
Pergunto eu, esta sociedade se compõe de nacionais ou também de estrangeiros? (...) A sociedade brasileira contém tão somente homens livres ou também escravos? A sociedade do império brasileiro compõe-se de nacionais e de estrangeiros, de livres e de escravos. (...) abaixo se trata dos brasileiros sem se marcar quais são os que devem assim chamar-se [refere-se aos artigos do capitulo em discussão]. Tratou-se dos direitos individuais dos brasileiros e depois dos seus direitos políticos e, no fim, dos seus deveres. E não se disse coisa alguma a respeito dos direitos nem dos deveres dos estrangeiros e dos escravos. Ora, meus srs., é verdade que a associação brasileira se compõe de nacionais, estrangeiros, libertos ou escravos, ou não? ${ }^{14}$

Portanto, diferenciar entre ser brasileiro e ser cidadão significava reconhecer para escravos e indios selvagens a primeira condição, não silenciando na constituição sobre sua existência, sem contudo Ihes conferir qualquer tipo de cidadania. Venceu afinal a posição de Vergueiro, pela qual, se definia naquele capitulo quem eram os cidadãos brasileiros, sem diferenciar brasileiro de cidadão brasileiro. A mesma fórmula foi consagrada na constituição de 1824.

Definidos constitucionalmente os critérios de exercício da cidadania, a discussão sobre quem era representante e quem tinha direito de ser representado continuou no decorrer de todo o século XIX, especialmente através de freqüentes reformas na legislação eleitoral.

No que diz respeito à exigência de renda não houve alterações legais a não ser a indexação à prata dos valores previstos pela constituição, consagrada em lei promulgada em 1846. Outros foram os temas que mobilizaram os legisladores na definição da relação de representação. 0 intenso debate sobre a legislação eleitoral no Brasil oitocentista foi norteado pela convicção dos parlamentares de que as regras que normatizavam a escolha dos representantes eram fundamentais para determinar a qualidade destes. Em 1839, por exemplo, quando discursou sobre projeto de reforma eleitoral apresentado por comissão especial da Câmara e que resultaria na lei de 1846, o deputado Andrada Machado, afirmava

corrigir as faltas do governo democrático, bases das eleições populares, é de mais importância do que estender a esfera a que este governo se pode aplicar. Uma representação apresenta ao poder das multidões um contrapeso na influência das outras 
Anais da Câmara dos Deputados, sessão de 16/8/1839. classes: ela substitui legisladores hábeis a outros inteiramente incapazes de qualquer função legislativa; e continua a confiança uma vez depositada por todo o tempo suficiente para salvar a legislatura das ilusões e frenesi temporário do povo. ${ }^{15}$

Nesta fala aparece a crença de que o governo representativo dependia da qualidade dos representantes escolhidos e esta qualidade, por sua vez, dependia da realização de eleições que garantissem a melhor escolha possivel.

Neste sentido, foram basicamente quatro os temas que mobilizaram os parlamentares brasileiros. 0 primeiro deles, como já referido, dizia respeito à definição dos direitos de cidadania. 0 segundo problema era a fraude eleitoral, considerada um mal a ser vencido, de forma a garantir que as eleições expressassem a real vontade dos eleitores. Outro ponto era a representação das minorias, ou seja, garantir que os partidos que não obtinham maioria dos votos tivessem também representantes com assento no parlamento, de modo que este fosse uma espécie de reprodução da diversidade de opiniões políticas do pais, em um contexto em que não havia ainda a prática do voto proporcional. Por fim, os legisladores demonstravam constante preocupação com a influência do Executivo nas eleições e a combateram com as chamadas incompatibilidades, ou seja, a proibição de que determinados funcionários públicos, como magistrados e agentes da administração, fossem candidatos a deputado. Os quatro temas respondiam a preocupações de fundo, referentes à efetividade do governo representativo: o tipo de representação que deveria prevalecer e a independência entre os poderes.

Os quatro temas freqüentaram os debates parlamentares desde pelo menos 1828 e, entre outras leis, as opções adotadas materializaram-se em cinco mais importantes: a lei de 1846, que criava mecanismos mais rigorosos para a aplicação dos artigos constitucionais sobre o exercício do voto, a lei de 1855 que adotava o que os políticos da época denominavam de voto distrital (que na verdade significava a opção por distritos pequenos no lugar do grande distrito provincial) e restringia o direito de elegibilidade de detentores de determinados cargos públicos (incompatibilidade), a lei de 1860 que reviu o tamanho dos distritos e substituiu o voto uninominal pelo plurinominal, a lei de 1875 que introduziu o título de eleitor e que retornou ao distrito provincial e a lei de 1881 que modificou os princípios de cidadania, ao substituir as eleições em duas fases pela eleição direta, eliminando a figura do votante e introduzindo a exigência de alfabetização, além de retomar o voto distrital uninominal. Embora cada uma delas tenha se centrado em pontos específicos, as questões mencionadas acima permearam todo o debate. Por exemplo, na discussão da lei promulgada em 1846, o chamado voto distrital foi um tema importante, embora ele só fosse consagrado pela lei promulgada em 1855. 0 que indica que as reformas eleitorais do império giraram em torno sempre dos mesmos pontos centrais, sendo que os deputados faziam opções diferentes, em diferentes momentos, variando conforme os percalços da prática eleitoral.

As discussões sobre a legislação eleitoral tiveram início em 1828, ou seja, apenas dois anos depois que o parlamento começou a funcionar, mas somente em 1846 estes debates teriam como resultado uma nova lei que revia algumas das determinações estabelecidas pela constituição de 1824. Neste momento, a preocupação central dos parlamentares era regularizar o processo eleitoral de modo a evitar as fraudes. A historiografia tem enfatizado como a prática recorrente da fraude e da violência acabou por falsear 
16

Anais da Câmara dos Deputados, sessão de 13/11/1841.

Anais da Câmara dos Deputados, sessão de 16/8/1839. a representação política. Esta é uma questão que, ao meu ver, precisa ser revista. Que a fraude existia é indiscutivel, mas sua magnitude é de difícil aferição. 0 que sabemos sobre a fraude vem de relatos interessados, de homens envolvidos na política a cujos projetos servia pintar um quadro de fraude avassaladora. É o caso do texto do Belizário Soares de Souza, 0 sistema eleitoral no Império, publicado em 1872, sempre citado quando o assunto são as fraudes eleitorais. 0 problema é que, como político, Belizário defendia o fim das eleições em duas fases, com a exclusão dos votantes e seu principal argumento era que isto eliminaria a fraude ao retirar do processo eleitoral indivíduos não qualificados para votar com consciência. Além disso, é preciso considerar que a fraude não era privilégio brasileiro. Ela era fartamente praticada na Europa e nos EUA. A história dos governos representativos foi, entre outras coisas, a história da gradativa conquista do controle sobre as eleições de modo a reduzir drasticamente as práticas fraudulentas. Os debates no parlamento brasileiro sobre a legislação eleitoral demonstram que esta era também uma preocupação constante da elite política nacional.

Embora o foco principal em 1846 tenha sido a regularização do procedimento eleitoral, para melhor combater as fraudes, e a definição da cidadania, uma vez que a indexação à prata preservava o valor do censo exigido para a participação nas eleições, os outros dois temas acima citados estiveram presentes no debate. A definição de incompatibilidades foi então rejeitada, mas permeou o debate na medida que eram previstas em um dos projetos em discussão, de autoria do deputado Carneiro da Cunha, que determinava não serem "elegíveis os presidentes nas províncias que administrarem, os bispos em suas dioceses, os desembargadores nos distritos de suas relações, os comandantes das armas nos lugares de seus comandos, os chefes de polícia, seus delegados e subdelegados nos termos ou distritos de sua jurisdição; (e) os juizes de direito em suas comarcas"16. A proposta gerou imediata reação dos demais deputados que argumentavam ser ela inconstitucional, sugerindo que ela fosse à comissão de Constituição e Justiça. 0 tema voltaria na reforma de 1855 .

0 outro ponto, a representação das minorias, materializou-se na forma da discussão sobre o voto distrital. Aqueles que o defendiam argumentavam que a eleição de deputados por distritos pequenos garantiria que os grupos minoritários, sem influência em toda a província, poderiam eleger alguns deputados, proporcionalmente à sua força política. Quando da apresentação do projeto em 1839, a comissão encarregou-se de justificar porque o voto distrital não constava de sua proposta. 0 deputado Andrada Machado, membro da comissão, explicava a opção da mesma, antecipando os argumentos utilizados por aqueles que fariam oposição ao voto distrital quando este voltou a ser discutido em 1855:

restava o expediente de dividir a província em distritos eleitorais de um ou dois deputados, não havendo neste caso dificuldades de tornar efetiva a pluralidade absoluta. Mas se com este expediente se evitava o mal das corvéias, outro mal maior pareceu a comissão dever dai derivar. Ela capacitou-se que semelhante divisão não faria senão enviar ao corpo representativo notabilidades de aldeia, em vez de verdadeiras notabilidades provinciais ${ }^{17}$.

0 debate sobre o voto distrital retornaria em 1855 diante da preocupação com a garantia da representação das minorias. A questão de fundo era encontrar um mecanismo que impedisse as câmaras unânimes, ou seja, 
18

RONSAVALLON, Pierre. La consagración del ciudadano: Historia del Sufragio Universal en Francia. San Juan: Instituto Mora, 1999. p.197. nas quais apenas um partido detivesse todas as cadeiras. Como o sistema proporcional ainda não era usual na Europa, tendo sido introduzido só no final do século XIX, a preocupação em garantir a eleição das minorias tinha que ser resolvida dentro do sistema majoritário. Em 1855, no debate que resultou na promulgação da Lei dos Círculos, os parlamentares optaram, não sem muita discussão, pela adoção do voto distrital, em substituição ao chamado voto provincial, consagrado na Constituição de 1824. No esforço de garantir a representação minoritária sem voto proporcional, a proposta era que o voto fosse por distritos pequenos, ao invés do grande distrito provincial. Não estava em jogo, na verdade, dois sistemas diversos, pois o voto provincial também era distrital, já que cada província elegia um número fixo de deputados e cada eleitor votava em tantos nomes quantos deputados compunham a bancada de sua província, sempre pelo sistema majoritário.

Os defensores do voto por distritos pequenos consideravam esta uma forma mais eficiente para garantir a eleição de minorias no sistema majoritário, uma vez que bastaria ter poder local para ser eleito, enquanto uma circunscrição ampla como a província favoreceria o candidato melhor articulado politicamente e assim tornaria quase impossivel a eleição de candidatos de grupos minoritários.

Nos Estados Unidos e na França também o debate sobre distritos grandes e pequenos polarizou a discussão. No primeiro, os federalistas alinharam-se em defesa do distrito grande, com o argumento de que este favorecia a eleição dos mais capazes, enquanto os anti-federalistas advogavam o distrito pequeno como forma de garantir a eleição de representantes semelhantes aos seus representados. Na França, o debate ocorreu quando da aprovação da lei de 1817 que substituía a eleição em dois graus pela direta. A lei previa que os eleitores deveriam se concentrar na capital do departamento para escolher os seus representantes, ao contrário da votação por distritos pequenos que prevalecera até então. Também neste caso se digladiavam duas concepções de representação: a defesa da representação baseada na semelhança, abraçada pelos ultrarealistas, e a da representação dos melhores, advogada pelos liberais ${ }^{18}$. Tanto federalistas norte-americanos como liberais franceses consideravam que os distritos pequenos favoreciam a eleição das notabilidades de aldeia, comprometendo assim a qualidade da representação, enquanto seus antagonistas os defendiam em nome da representação da diversidade. Eram concepções de representação distintas que estavam em pauta. Da mesma forma, no Brasil, o debate girou em torno de concepções diversas.

Os defensores do chamado voto provincial argumentavam que a vontade nacional prevaleceria na medida que fossem eleitos os individuos mais virtuosos, o que seria garantido pelo distrito grande. Ao contrário, o chamado voto distrital, ao privilegiar os potentados locais, tornaria inviável que a assembléia eletiva fosse o espaço de formulação do "bem comum". 0 deputado pelo Ceará, o conservador João Capistrano Bandeira de Mello, no debate em 1855, em torno do projeto que estabelecia os círculos pequenos, posicionou-se contrariamente argumentando que

A imprensa não funciona nessas localidades, nelas é nula ou quase nula a ilustração. As comunicações do nosso país são morosas e dificeis, não se pode por conseguinte formar nessas localidades uma opinião que Ihes seja própria, principalmente com relação aos interesses gerais, e se alguma opinião se forma sobre eles, no estado da nossa ilustração, falo em geral, não pode deixar de ser uma má 
Anais da Câmara dos Deputados, sessão de 29/8/1855.

\section{0}

Anais da Câmara dos Deputados, sessão de $27 / 8 / 1855$.

21

Anais da Câmara dos Deputados, sessão de $25 / 8 / 1855$.

22

Ibidem. opinião, filha de pequenas paixões, de ressentimentos, de rivalidades locais. Ora, semelhante opinião não pode ter cabimento em uma assembléia a quem a constituição incumbe promover o bem geral da nação. 19

Nos mesmos termos se manifestava o deputado pelo Sergipe, João de Siqueira Queiroz, em oposição ao projeto que consagrava os distritos pequenos:

E se o governo não ganha com essas medidas, quem é que há de ganhar, senhores? Serão as influências locais para virem representar na câmara, o que senhores? Os interesses locais? Pois a câmara deve representar os interesses das localidades ou os interesses gerais? Pois os nobres deputados que querem a representação nacional em toda a sua pureza podem acreditar que venham as influências das localidades representar os interesses da nação? 20

A tensão também no Brasil estava entre uma concepção que identificava representação com escolha de representantes que carregassem as virtudes necessárias para se pautar de acordo com o bem comum e que, portanto, deveriam ser ilustrados, em oposição a uma idéia de representação por semelhança. Esta última era defendida pelos advogados do projeto de lei como forma de garantir o real interesse nacional. 0 deputado pela Bahia Eduardo Ferreira França afirmava que o interesse geral nascia da semelhança entre representante e representado:

Os representantes devem se identificar o mais possivel com os interesses dos seus representados, devem conhecer as necessidades destes, e os meios de satisfazê-las, defendendo os seus direitos. (...) o que é o interesse geral senão a fusão e a combinação dos diferentes interesses locais? E como é possível que sem serem representados esses interesses locais, sem serem conhecidos os elementos que constituem o interesse geral, possa esse interesse geral ser conhecido e satisfeito? ${ }^{21}$

Nesta perspectiva, interesse geral é entendido não como a formulação a partir de representantes qualificados para tanto, mas como resultado da reunião das vontades individuais:

Os direitos e interesses dos cidadãos hão de ser mais bem garantidos com a decretação dos círculos, porque hão de ser mais bem conhecidos. 0 interesse geral há de ser mais bem aquilatado e defendido, porque ele não consiste senão da combinação dos diferentes interesses individuais. 22

Assim, nesta concepção as eleições por distrito pequeno garantiam uma melhor representação. Da mesma forma o deputado conservador pela Bahia, Benevuto Augusto de Magalhães Taques dizia não só não temer que as notabilidades de aldeia tomassem conta da Câmara, como afirmava que a eleição por distrito de um deputado era a única forma de fazer valer o interesse nacional, uma vez que este era a soma das vontades espalhadas pelo território:

Devemos desejar ter nas Câmaras não só os indivíduos mais capazes pelo seu talento e saber, como também aqueles que melhor conheçam as circunstâncias do país, os seus interesses, não só tais como se manifestam na Corte e nas grandes capitais das províncias, mas como se sentem em todo o território brasileiro, onde esses interesses são muito variados. (...) É só reunindo e conhecendo as opiniões das diversas localidades do império que se poderá obter a expressão da opinião nacional 23 . 
24

Anais da Câmara dos Deputados, sessão de 9/6/1860.

25

Ibidem.
A lei dos círculos foi aprovada em 1855. Não só os deputados passaram a ser eleitos por distritos pequenos, como o número total deles elevou-se de 113 (número de deputados na legislatura de 1853-1856), para 235 (número de deputados na legislatura de 1857-1860). A bancada de cada provincia dobrou e algumas poucas tiveram sua representação aumentada para além do dobro. A província com maior representação na Câmara, Minas Gerais, passou a contar com 40 deputados, de 40 distritos. A segunda maior, Bahia, foi dividida em 28 distritos para formar uma bancada de 28 deputados. Pernambuco passou a contar com 26 deputados, Rio de Janeiro com 24, São Paulo 18, Ceará 16.

Na primeira legislatura eleita pela lei dos círculos a legislação foi novamente reformada. Lei promulgada em 1860 reviu o tamanho dos distritos aumentando-os consideravelmente. A maioria dos deputados expressou então uma análise negativa sobre a experiência eleitoral regrada pela lei de 1855, embora tenham sido por ela eleitos. A nova reforma pretendia chegar a um arranjo intermediário: nem o grande distrito provincial, nem o pequeno distrito de 1855. Distritos maiores favoreceriam a escolha de representantes considerados melhores qualificados para definir o interesse geral por não se confundirem com os poderes locais, ao mesmo tempo em que se procurava garantir a representação das minorias, considerada inviável com o voto provincial. A província, assim, era dividida em distritos, mas consideravelmente maiores do que aqueles previstos em 1855. Em Minas Gerais, por exemplo, os 40 distritos da lei dos círculos foram substituídos por apenas sete, na Bahia 28 distritos deram lugar a 5, mesmo número de distritos de Pernambuco, em substituição aos 26 anteriores. A outra novidade introduzida pela lei de 1860 foi que cada distrito elegeria três deputados, retornando-se ao total de deputados na Câmara existente antes de 1855. Cada eleitor deveria votar em três nomes, sendo eleitos os três que obtivessem a maioria dos votos do distrito.

A comissão especial que apresentou o novo projeto de lei eleitoral em 1860 resumiu na sua introdução as questões em jogo:

No regime eleitoral antigo [refere-se ao regime anterior a 1855, ou seja, o voto provincial previsto pela Constituição de 1824], aconselhado pela constituição do Império, imperava o princípio de que o eleitor devia intervir na escolha de todos os representantes de sua província. As faculdades do eleitorado tinham então a grandeza dos interesses coletivos provinciais. 24

No entanto, segundo o parecer, este sistema acabou não dando os resultados esperados, uma vez que

As câmaras unânimes derivavam-se da confraternidade de vistas, de interesses, e até das paixões do eleitorado de província. E como se queria achar a regularidade do nosso sistema político no embate das opiniões no recinto da Câmara temporária, procurou-se destruir esta confraternidade, fazendo dos eleitores de província eleitores de pequenos distritos. ${ }^{25}$

0 problema dos pequenos distritos uninominais, segundo a comissão, estava que a eleição gerava o inconveniente de

Modificar profundamente o caráter do eleitorado, impondo-Ihe tendências contrárias aos verdadeiros e grandes interesses políticos do Império. Ninguém que tenha estudado e acompanhado as modificações que a última reforma eleitoral imprimiu 
Anais da Câmara dos Deputados, sessão de 9/6/1860.

27

Ibidem.

28

Anais da Câmara dos Deputados, sessão de 18/6/1860.

29

Anais da Câmara dos Deputados, sessão de 19/6/1860.

30

Anais da Câmara dos Deputados, sessão de 20/6/1860. no espírito público (...) terá deixado de observar com dó o predomínio que vai obtendo o interesse individual sobre o interesse coletivo. ${ }^{26}$

A proposta era encontrar uma espécie de meio termo, conforme expressa a comissão, ao afirmar que pretendia "harmonizar os dois principios extremos e evitar os inconvenientes de cada um deles"27. Propunha assim o alargamento dos distritos que deveriam deixar de ser uninominais para serem plurinominais. Procurava-se um método que, ao mesmo tempo, evitasse as câmaras unânimes e as eleições feitas pelos potentados locais.

No debate que se seguiu, uma minoria de deputados se opôs ao projeto com o argumento principal de que ele significava a volta das câmaras unânimes, ou seja, o abandono dos distritos pequenos de um deputado era o abandono da representação das minorias. Neste sentido se manifestou o deputado F. Octaviano:

Não vos lembrais, senhores, que dentro do parlamento um partido era unânime, obrigando o outro lá fora a estas cenas de agitação que devemos condenar, esquecer e nunca provocar de novo? É esse o espírito político que voz apraz? ${ }^{28}$

Em resposta, o deputado Saraiva justifica a reforma como o melhor caminho para neutralizar as influências locais:

Dar a um pequeno número de eleitores o direito de fazer um deputado é excitar os interesses individuais, é dar ganho de causa aos interesses pessoais, locais, sobre os interesses públicos, sobre os interesses nacionais. (...) Círculo de um deputado em regime de eleição indireta é a representação mais brilhante do princípio oligárquico em todos os pontos do Império. 29

Assim, se a representação das minorias foi uma preocupação constante da elite política ao longo do período, os problemas a serem enfrentados para garanti-la também eram os mesmos. Optar pelo distrito pequeno, estimulando a eleição de representantes do partido minoritário, significava dar um conteúdo específico à representação, pois os representantes eleitos estariam vinculados aos potentados locais. Optar por uma escolha de representantes comprometidos com interesses mais gerais, sem vínculos diretos com as notabilidades de aldeia, através do voto provincial, significava correr o risco das câmaras unânimes. Mesmo quando se tentou uma solução que ficava no meio termo, como o projeto de 1860, o debate se polarizou entre estas opções. Acabou vitoriosa a posição defendida em plenário pelo ministro do Império, Almeida Pereira:

0 gabinete, adotando o projeto que se acha em discussão, procurou evitar ambos os inconvenientes, procurou não matar o espírito local, mas dar-Ihe maior expansão. Não procurou também restaurar o antigo sistema pelos inconvenientes que algumas vezes trouxe este sistema. 30

As novas regras prevaleceram por 15 anos. Em 1875, nova reforma reintroduziria o voto provincial. Mas não por muito tempo, em 1881 novamente seria adotado o distrito pequeno de um deputado.

Obviamente os debates e as reformas eleitorais foram decisivamente marcados pela conjuntura política específica de cada momento. Mas, para além disso, o que se procurou demonstrar é que a elite política brasileira estava também comprometida com o governo representativo e esforçavase por normatizá-lo, tendo em vista não apenas interesses concretos, mas 
também princípios e questões que diziam respeito a como este governo deveria funcionar. Enfrentou problemas comuns aos demais governos representativos do século XIX, como a garantia da representação da minoria, e buscou soluções dentro do repertório político da época, mas sem perder de vista a experiência concreta e as especificidades nacionais. Na busca de uma solução, enfrentou dilemas comuns a todos os governos representativos do periodo: deveria prevalecer um sistema em que se garantisse a escolha de representantes notórios por suas virtudes e assim melhor capacitados para definir quais eram os interesses nacionais ou, de outro lado, deveria ser consagrado o princípio da semelhança, de modo que a Câmara fosse uma espécie de retrato das divisões políticas presentes na sociedade. Empenhados na construção do governo representativo, tal como ele era entendido no século XIX, um governo excludente de elite, mas que tinha algum grau de representatividade, consideraram as câmaras unânimes e a fraude problemas a serem resolvidos e a solução deveria estar, como em qualquer governo representativo da época, na legislação que regrava as eleições. 